\title{
PRONUNCIATION PROBLEMS AND THE APPLICATION OF PROCESS SKILL APPROACH: A CASE STUDY OF MECHANICAL ENGINEERING STUDENTS AT UNIVERSITAS MUHAMMADIYAH YOGYAKARTA
}

Yashinta Farahsani

Department of Mechanical Engineering, Faculty of Engineering Universitas Muhammadiyah Yogyakarta

\begin{tabular}{|c|c|}
\hline ARTICLE & ABSTRACT \\
\hline Keywords: & $\begin{array}{l}\text { Mastery of English as an international language is a demand that must be } \\
\text { developed along with the times. In one of the subjects that must be taken by }\end{array}$ \\
\hline Pronunciation, & students of Mechanical Engineering UMY is English: Writing and \\
\hline presentation, & $\begin{array}{l}\text { Presentation. Some of the difficulties encountered in making presentations } \\
\text { were their lack of knowledge about public speaking, so that the presentations }\end{array}$ \\
\hline process skill approach, & $\begin{array}{l}\text { seemed monotonous and unattractive. In addition, when making } \\
\text { presentations in English, the biggest obstacle is the pronunciation problem. }\end{array}$ \\
\hline students of Mechanical & In this study, the writer examined the application of appropriate learning \\
\hline Engineering $U M Y$ & $\begin{array}{l}\text { method for pronunciation learning so that students were able to optimally } \\
\text { pronounce each word in English. In the results of observation and }\end{array}$ \\
\hline & simulation, the writer found 4 (four) students' difficulties of learning English, \\
\hline & $\begin{array}{l}\text { 1) they tended to say in accordance with the spelling, 2) they found difficulty } \\
\text { with vocabulary ending in '-ed', 3) they found difficulty with diphthong } \\
\text { sounds, 4) they found difficulty in pronouncing words with sounds that are } \\
\text { almost the same in other words. Thus, drilling is done to improve it which } \\
\text { includes manner of presentation and pronunciation. }\end{array}$ \\
\hline
\end{tabular}

\section{INTRODUCTION}

Mastery of English as an international language is a demand that must be developed along with the times. Asthe present generation that is the hope of the country, students are expected to be able to master foreign languages, especially English, in addition to the background of their knowledge. This is because, English is very important for them, especially when they go abroad, for example in terms of continuing their studies or looking for work. However, in general, English skills of students in Indonesia are inadequate. 
One of the subjects that must be taken by Mechanical Engineering students of UMY is English: Writing and Presentation. In the course, students learn to write with additional skills that must be learned are grammar and speaking with the focus on presentation (public speaking). Some of the difficulties encountered in making presentations were their lack of knowledge about public speaking, so that the presentations seemed monotonous and unattractive. In addition, when making presentations in English, the biggest obstacle is the pronunciation problem. Given that Indonesian students come from various ethnic groups with different regional languages, the ability to pronounce English is different because of the differences in the phonological aspects of each regional language.

In this study, the writer examined the application of appropriate learning method for pronunciation learning so that students were able to optimally pronounce each word in English. The results of the study that discussed the difficulties in pronunciation in English have been many, but research that addresses the learning process tends to be still few. That is the reason why the writer wants to study the application of pronunciation learning method by process skill approach.

Pronunciation is a person's ability about how someone understands the sound system, and has an impact on someone's speech that will directly influence the meaning in the English context. In English, different sounds will produce different meanings. This affects how a person communicates verbally, whether the meaning of the sound produced can be understood properly by the opponent or not. The weakness of Non-English speakers is that it is difficult for them to pronounce English vocabulary because of the difference in sound with their mother tongue. Therefore, the existence of English language courses has a purpose, one of which is teaching how students can pronounce English vocabulary correctly and clearly.

\section{Statement of Problem}

A close observation of Mechanical Engineering students at UMY found out that students were confused of the pronunciation of some set of words. Sucihati (2015) mentioned that there are a number of vocals in English that do not appear in Indonesian. A number of English consonants also do not appear in Indonesian. In Indonesian, there are 


\section{JEASP}

Journal of English for Academic and Specific Purposes

Volume 1 Number 2, December, 2018

also known diphthongs, but do not have clusters. Clusters in Indonesian only occur in the borrowing word, which is a word that is absorbed from another language. In this case, clusters in Indonesian are adopted from English. For example, strategy /strategy/, structure from /structure/, instruments from/instrument/, and so on. In English, stress is very important because it influences the meaning of a word, whereas in Indonesian the stress is not so important because it does not affect the meaning of a word. In addition, in English, there is an aspirated sound, which means the sound accompanied by the air blowing that follows when spoken. A number of sounds in English are not found in Indonesian, and sounds in both languages that have the same place of articulation actually have different ways of articulation. Basically, the Indonesian sound system is similar to the English sound system.

The researcher spent one semester observing the pronunciation of English words by the students of Mechanical Engineering UMY and found three results, they are:

a. Students tend to say according to the spelling, e.g. 'background' was pronunced /bæk.gro:n/, 'produce' was pronunced /pro'du:k/, and 'nature' was pronunced /'na:tu:r/

b. Students have difficulty with vocabulary ending in '-ed', e.g. 'fulfilled' was pronunced /fol' fıIld/, 'mixed' was pronunced /'miksət/, and 'called' was pronunced /ka:ləd/.

c. Students have difficulty with diphthong sound, e.g. 'find' was pronunced / fi:n/, 'by' was pronunced /bi:/, and 'about' was pronunced /a'bo:t/.

It is not easy for a foreign language learner to speak with native-like pronunciation. Therefore, this research attempts to identify the problematic areas of pronunciation and to identify the exact reasons behind them and to try to find suitable techniques that help the students to speak English with better pronunciation, which one of them is using process skill approach.

\section{Research Purposes}

Based on the formulation of the problem, the purpose of this study is:

a. To find out what difficulties students face in English pronunciation when making presentations in English. 


\section{JEASP}

Journal of English for Academic and Specific Purposes

Volume 1 Number 2, December, 2018

b. To find out how the process approach is applied to improve students' pronunciation skills when making presentations in English.

\section{LITERATURE REVIEW}

\section{Problems of Indonesian Students Pronunciation}

Laila (2009) in her paper stated that The pronunciation of the sound is divided into consonant, vowel and diphthong sounds. In the description of consonant sounds, the pronunciation of students is less energy or lack of aspiration. Their articulation is only done by not exerting maximum pressure so that the pronunciation of the consonant sounds is more sluggish. In the pronunciation of vowels, students have a tendency to say the phoneme rather than the sound. This is as seen in the shifts made in the pronunciation of diphthong sounds. Sound shift is divided into shifts of vowels and consonants. The thing that often happens as a category of shifting vowel sounds is when students pronounce double vowels or diphthongs. Therefore, the classification of diphthong sound shift is in the classification of shifting vowel sounds. Whereas what can be included as a shift in consonant sound is a symptom: noise reduction, omission, insertion, retardation, forwarding, and consonant sound replacement.

\section{Problems in Speaking English in Front of Public}

Kustanti (2017) mentioned that The difference between the speaking habits of the Indonesian tongue and the tongue-speaking speaker is the cause of the difficulty of English pronunciation. The thing that must be considered in learning English is listening skill or auditory ability to vocabulary in English. In Indonesia there are only two systems of vowel sounds and consonant sounds while in English it has more than two systems of vowels, diphthongs, consonants and clusters.

She also said that English courage can be done with us, we should not be afraid of being wrong, because we can always learn any mistakes we do, and conversation is the best way to learn English. The quickest way to be able to communicate using English like native speaker is to communicate directly with the native speaker itself, if it cannot be fulfilled, we 


\section{JEASP}

Journal of English for Academic and Specific Purposes

Volume 1 Number 2, December, 2018

can listen to it and listen to how a native speaker communicates. The more often we listen to a native speaker, the more trained our hearing will be to the pronunciation used. Some ways to overcome pronunciation difficulties are (1) often practice and remember difficult words, except how to say words or sentences, (2) often open an English dictionary because there is usually a way to pronounce the word in the dictionary.

\section{The Application of Process Skill Approach}

Many researches has been carried out on the process approach, not only for English language courses, but also for other fields. In addition, the application of the process approach can be carried out not only within the scope of the university. More often, the process approach is applied in schools for the learning process of their students. Hosnan (2014: 370), the process skills approach is an approach in the teaching and learning process that emphasizes the skill of acquiring knowledge and communicating the acquisition. Mahmudah (2016) had two findings in her paper, those are:

1. Types of process skills that can be trained in students are observation, classification, space / time relationships, using numbers, inference, communication, predicting, controlling variables, formulating operational definitions, interpreting data, formulating hypotheses, and conducting experiments.

2. The importance of the process skills approach to learning in schools is that the teacher guides and educates students to be more skilled in using their experiences, opinions, and findings. A conducive learning atmosphere can encourage students to actively participate, by formulating detailed observations, classifying subject matter absorbed from observation activities. Students can communicate the results of their observations, can conclude a problem, events based on facts, concepts, and known principles.

From various studies conducted, many process skills approaches have been conducted to teach non-English subjects. Therefore, the authors develop an application theory of process skills approaches to improve students' pronunciation abilities. 


\section{JEASP}

Journal of English for Academic and Specific Purposes

Volume 1 Number 2, December, 2018

\section{METHOD}

This study is a qualitative descriptive research. The research subject was taken from students of Mechanical Engineering Study Program. The object of the research was pronunciation that was observed in students' presentation performances. The techniques of data collection were questionnaire and documentation methods. Questionnaire mothod was used to find data about students' opinions (open questinnaires) and documentation method was used to find data about things that has been determined. By using these methods, the writer could use free sentences.

First step of data collection technique was spreading questionnaires to the students to see how far they know about English, what are the difficulties, ang how are the solutions. While performing documentation technique is to collect data from the students' performances. The second step was data analysis. Since this research tried to find the pronunciation difficulties, to analyze the data, this research used phonological analysis. The last step was identification and classification. During this step, the data were identified and classified based on their category, meaning and usage. The instruments used in this research were laptop and cell phone.

This type of research is classroom action research. The procedure of this research can be carried out in several stages described in the following figure: 


\section{JEASP}

Journal of English for Academic and Specific Purposes

Volume 1 Number 2, December, 2018

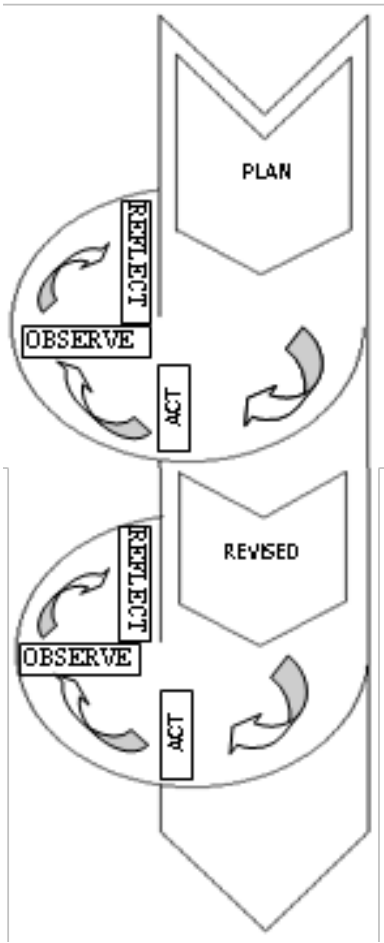

Figure 1: Kemmis and Taggart Mode

Based on the research procedure, the research was carried out in several stages. The first stage: (1) plan, (2) act, (3) observe, (4) reflect. The second stage (1) is revised plan, (2) act, (3) observe, (4) reflect. Some of these grooves will be adapted to the conditions when the research is ongoing with the possibility of addition or reduction according to research needs.

\section{FINDING AND DISCUSSION}

\section{Course of English: Writing and Presentation}

English (Writing \& Presentation) course is the continuation from the previous semester (ie Reading \& Listening) that students must take. This course supports students' competencies to express ideas using acceptable and coherent English with the correct linguistic elements and in the context related to problems, problem solving methods and the results of a solution in the field of Mechanical Engineering. 


\section{JEASP}

Journal of English for Academic and Specific Purposes

Volume 1 Number 2, December, 2018

This course focuses on two English language skills, writing and speaking, in an academic context. The purpose of general instruction from this course is that students are expected to be able to express ideas by having complete paragraph in writing skills and presentation skills in accordance with the paragraphs that have been written using acceptable and coherent English with correct and contextual linguistic elements.

Especially for writing skills, students are expected to understand the whole sentence principle. Students are also expected to be able to present ideas in writing in the form of topic sentences, supporting sentences, and concluding sentences combined into whole paragraphs. Apart from that, students are also able to apply punctuation, spelling, and use of capital letters properly.

Especially for presentation skills, students are expected to understand the principles of formal expression. Students are also expected to be able to express ideas verbally by using correct and context-relevant signposting. Apart from that, students are also able to present effective visual aids and use good body language.

\section{Student Difficulties in English Pronunciation \\ Relationship of English with Mother Tongue Language}

Students of Mechanical Engineering study program UMY come from various regions spread throughout Indonesia, with different mother tongue (L1), for example Javanese, Sundanese, Karo Batak, Bugis, Minang, Banjar, and others. Not a few also use Indonesian as their mother tongue. Of course this affects the use of a second language or a foreign language, for example English (L2). This influence is usually seen from the way they speak in everyday language or formal language when speaking in public, for example the existence of code-mixing, code-switching, or in pronunciation.

In addition, students got English lesson from different levels of education, and the majority getting English lesson since the elementary level is 66.67\%. Some even got English lessons from kindergarten, which was $26.09 \%$, and since junior high school was $7.25 \%$. The level of education in which students get English subjects cannot be a benchmark for how fluent they are able to speak in English because of several factors:

a. Different ways to teach English with different teachers and methods. 


\section{JEASP}

Journal of English for Academic and Specific Purposes

Volume 1 Number 2, December, 2018

b. Desire from one's own person to want to learn English without coercion.

c. The frequency level of the exercise speaking in English, both with friends or alone.

So it can be concluded that the level of education does not guarantee the ability of students to speak English well and fluently. Mother tongue (L1) does not significantly affect the pronunciation of English (L2). The pronunciation difficulty problem does not originate from B1 used by students, because many surveys say that the Indonesian tongue is the most flexible to pronounce various foreign language vocabulary, especially English without the obvious accent of their native language. So the message to be conveyed will be clearly conveyed.

\section{Students' Difficulties in Learning Pronunciation}

Many students feel that learning English is difficult. They have difficulties in various English skills, namely reading, listening, writing, speaking, and grammar. Each skill presents its own challenges. In reading skills, students are required to be able to develop English vocabulary. In writing skills, they are required to master English grammar, which is syntactically, the sentence structure of English is the same as Indonesian, namely SubjectPredicate-Object-Adverb. However, the difficulty is the different verb forms (V1-V2-V3) used at different times. In listening skills, students are required to understand what they hear. The difficulty of this skill is that they are unable to capture every sound spoken in English. The last is speaking skill which is the toughest challenge because they have to speak using English with the right pronunciation.

There are a number of points that make it difficult for students to pronounce English vocabulary because of differences in sounds with Indonesian, namely vowel sounds, consonant sounds, and word stress. Students argue that they have difficulty speaking English, especially because of the difference between sound and spelling, so they have to practice to be able to pronounce English vocabulary. Thus, they concluded that they must learn to improve their English language skills because English is an international language. 


\section{JEASP}

Journal of English for Academic and Specific Purposes

Volume 1 Number 2, December, 2018

\section{Students' Difficulties of Delivering Presentation in the Public}

Two common difficulties were found in students when making presentations in public, namely a lack of confidence and lack of English skills. Both of these difficulties are overcome by personal preparation.

The first difficulty is lack of confidence. This is an obstacle because students will feel nervous when speaking in public. As a result, they cannot speak smoothly, either by reading text or without text. This problem can be overcome by holding a simulation session before the day of the presentation so that students are better prepared and more confident.

\section{Data Findings}

The second difficulty is the lack of English skills. There are two problems in this case, namely the lack of mastery of English vocabulary and not being able to pronounce English vocabulary properly. To overcome this problem, in addition to holding simulation sessions, students are also asked to make notes for presentation material. Plus, they have to practice at home to be able to pronounce English vocabulary well.

During the observation and simulation period, the writer obtained several findings, related to the problem of pronunciation and manner of presentation. The author found 4 difficulties in students in pronouncing English vocabulary:

a. Tend to say according to the spelling

The most common problem is that students tend to say vocabulary according to their spelling. This is influenced by the use of the Indonesian language in which the pronunciation is in accordance with the spelling, for example:

$\begin{array}{ll}\text { air } & \text { /air/ } \\ \text { kalau } & \text { /kalaw/ } \\ \text { intai } & \text { /intay/ } \\ \text { bukan } & \text { /bukan/ } \\ \text { cara } & \text { /cara/ }\end{array}$

Here are some examples of English vocabulary that are pronounced like the spelling:

\begin{tabular}{|l|l|l|}
\hline Word & $\begin{array}{l}\text { Phonetic } \\
\text { symbol }\end{array}$ & $\begin{array}{l}\text { Student's } \\
\text { pronunciation }\end{array}$ \\
\hline
\end{tabular}




\section{JEASP}

Journal of English for Academic and Specific Purposes

Volume 1 Number 2, December, 2018

\begin{tabular}{|l|l|l|}
\hline background & /bæk.graund/ & /bæk.gro:n/ \\
\hline produce & /pro'du:s/ & /pro'du:k/ \\
\hline matrix & /'meI.trrks/ & /'mstrrk/ \\
\hline nature & /'neI.tfə/ & /'na:tu:r/ \\
\hline about & /a'baut/ & /a'bo:t/ \\
\hline
\end{tabular}

b. Difficulty with vocabulary ending in '-ed'

The English V2 and V3 forms are divided into two, regular and irregular. In the regular category, verbs ending in '-d' or '-ed' are difficult to pronounce by students because each word will sound differently even though all end in '-d' or '-ed'. For example, the word replaced is pronounced / ripleIsd /, often students pronounce it to / riplesit /. Here are some examples of other vocabulary with similar problems:

\begin{tabular}{|c|c|c|}
\hline Word & $\begin{array}{l}\text { Phonetic } \\
\text { symbol }\end{array}$ & $\begin{array}{l}\text { Student's } \\
\text { pronunciation }\end{array}$ \\
\hline fulfilled & / fol'fild/ & /fol'fsıld/ \\
\hline mixed & /'mIkst/ & /'mIksət/ \\
\hline processed & /'pras est/ & /'prosesat/ \\
\hline called & /ka:ld/ & /ka:ləd/ \\
\hline designed & /di'zaInd/ & /də’signət/ \\
\hline
\end{tabular}

c. Difficulty with diphthong sound

Diphthong sound is an integral sound consisting of two different elements in quality. Usually, the composition of diphthongs is in English, one of the components is syllables. Diphthongs are considered top-down, if the syllables are the first component, and if the two diphthongs are upward. Examples of diphthongs in: [au], [ai], [ei], [o], [oi], [ie], [eu], [e], [e] made, late, how, house, fight, bone, coin, tear, cope, fair, sure. 


\section{JEASP}

Journal of English for Academic and Specific Purposes

Volume 1 Number 2, December, 2018

The difficulty that occurs in students is that they tend not to open their mouths to say diphthong sounds, especially for [au] and [ai] sounds. The following are examples of diphthong sound pronunciation errors by students:

\begin{tabular}{|l|c|c|}
\hline Word & Phonetic symbol & $\begin{array}{l}\text { Student's } \\
\text { pronunciation }\end{array}$ \\
\hline find & $/$ faInd/ & $/$ fi:n/ \\
\hline by & $/$ baI/ & $/$ bi:/ \\
\hline about & $/$ ' baut/ & $/$ ' bo:t/ \\
\hline type & $/$ taIp/ & $/$ tIpo/ \\
\hline down & $/$ daun/ & $/$ do:n/ \\
\hline
\end{tabular}

d. Difficulty pronouncing words with sounds that are almost the same in other words

Reciting English vocabulary is not easy, especially for words that have double consonants, double vowels, more than two syllables, and so on. Apart from these factors, the Indonesian tongue is also not used to saying English vocabulary. This makes it difficult for students to say certain vocabulary so that it is pronounced like the sound of another word. Here are some examples:

\begin{tabular}{|c|c|c|c|}
\hline Word & Phonetic symbol & $\begin{array}{l}\text { Student's } \\
\text { pronunciation }\end{array}$ & Pronunced Word \\
\hline constituent & /kən'stitf.u.ənt/ & /'ka:n.sti:tu:t/ & Constitute \\
\hline arrangement & /a'reInd3.mənt/ & / $\Lambda^{\prime} \mathrm{r} \Lambda$ nsəmen/ & $\begin{array}{l}\text { Aransemen } \\
\text { (Indonesian) }\end{array}$ \\
\hline molecular & /mo'lek.jə.la/ & /mo:klo:r/ & - \\
\hline first & /'f3r:st/ & /frIs / & \\
\hline reshape & /,ri:'SeIp/ & /rə’sep/ & $\begin{array}{l}\text { Resep } \\
\text { (Indonesian) }\end{array}$ \\
\hline
\end{tabular}

\section{a. The Application Process Skill Approach}

After taking data from students through simulation, the author gives direction by giving feedback to students and giving drilling for pronunciation for 2 (two) weeks. Drilling includes manner of presentation and pronunciation.

\section{1) Manner of presentation}




\section{JEASP}

Journal of English for Academic and Specific Purposes

Volume 1 Number 2, December, 2018

When students do simulations, there are still many things that must be improved to be able to deliver a presentation well. Manner of presentation is divided into two, namely manner and visual aids.

In a manner, students are drilled to be more confident in delivering presentations. In opening the presentation, students are trained to be more relaxed and deliver presentations by standing so that they can move more freely and can directly interact with the audience. In addition, students are also trained to be able to speak more loudly and clearly so that the audience can hear it well. When speaking, students are expected not to speak in a hurry because it will complicate themselves and the audience will find it difficult to capture the contents of the presentation.

While in visual aids, the most common mistakes are spelling errors and slides that are too full. Students are asked to recheck the power points that have been created and simulated, then correct the vocabulary that follows the spelling errors, written repeatedly, and grammatical errors. In addition, if in one slide consists of too many sentences or points, students are asked to reduce or include only important points.

In drilling manner of presentation, students only need to be accompanied and assisted for final checking.

\section{2) Pronuncation}

It has been mentioned in the previous point that students make a lot of English pronunciation errors so they need to be carefully trained in order to get maximum results. They were asked to practice at home, imitating vocabulary sounds in the online / offline dictionary. In addition, lecturer also provided training in the classroom by asking them to recite a number of vocabulary until they are correct and smooth.

\section{3) Individual Practice}

To overcome the pronunciation difficulties in English, students have several ways that can be applied in everyday life, namely:
a. Watch English movies 


\section{JEASP}

Journal of English for Academic and Specific Purposes

Volume 1 Number 2, December, 2018

Students can watch English movies with English subtitles. This method can improve pronunciation ability by imitating the language spoken by characters in the film. In addition, this method is also able to enrich their English vocabulary, both formal and informal.

b. $\quad$ Listen to songs in English

Students can also listen to English songs. Besides calming the mind, listening to English songs can also improve pronunciation skills if they are able to imitate the lyrics sung by the singer. They can read song lyrics while singing, so the sound produced is not careless.

c. Imitate pronunciation in the online / offline dictionary

Today, there are many online or offline dictionaries that are easily downloaded on the phone so that students do not need to carry a thick print dictionary while in an English class. In the dictionary application, in addition to the translated vocabulary, there is also a speaker to listen to the sound of the word. If students learn by using a print dictionary, they can learn by reading the phonetic symbol located next to the translated word.

\section{CONCLUSION}

Mastery of English as an international language is a demand that must be developed along with the times. Therefore, English language courses are compulsory subjects in each study program at the University of Muhammadiyah Yogyakarta, one of them is Mechanical Engineering study program. One of the courses taken by students is English 2 (Writing \& Presentation). In the course, students learning to write with additional skills that must be learned are grammar and speaking learning with the focus of learning on the presentation (public speaking).

In the results of observation and simulation, the writer found 4 (four) students' difficulties of learning English, 1) they tended to say in accordance with the spelling, 2) they found difficulty with vocabulary ending in '-ed', 3) they found difficulty with diphthong sounds, 4) they found difficulty in pronouncing words with sounds that are almost the same in other words. Thus, drilling is done to improve it which includes manner of presentation and pronunciation 


\section{REFERENCES}

Hosnan, M. (2014). Pendekatan Saintifik dan Kontekstual dalam Pembelajaran Abad 21. Bogor: Ghalia Indonesia.

Kustanti, Dewi danYadi Prihmayadi. (2017). Problematika Budaya Berbicara Bahasa Inggris. Jurnal al-Tsaqafa, 14(1).

Laila, Malikatul dan Hepy Adityarini. (2009). Pengucapan Bunyi Bahasa Inggris oleh Mahasiswa Jurusan Bahasa Inggris FKIP-UMS. Surakarta: Jurnal Penelitian Humaniora, 10(1).

Mahmudah, Laely. (2016). Pentingnya Pendekatan Keterampilan Proses pada Pembelajaran IPA di Madrasah. Kudus: Jurnal Elementary, 4(1). 